\title{
Modeling Environmental Performance and Economic Development
}

\author{
Jarita Duasa and Rafia Afroz
}

\begin{abstract}
The paper attempts to explore the contribution of economic development, population size or population density as well as the landlocked characteristic of the countries on the environmental performance using cross-sectional data of countries in the world listed by the United Nation (UN). The methods adopted in the present study are Ordinary Least Square (OLS) method and Generalized Method of Moments (GMM). Overall, using Environmental Performance Indicator (EPI) 2010 as a measurement of the effectiveness of national environmental protection effort, the present study finds that economic development/performance positively contributes to the countries' environmental performance. On the other hand, population size gives negative impact on the environmental performance of the countries.
\end{abstract}

Index Terms-Economic development, environmental performance index, generalised method of moments (GMM).

\section{INTRODUCTION}

Recently, most researchers are highly concern on the issue of 'sustainability', particularly on economic, social and environmental sustainability. The concept of sustainable development was emerged and introduced in 1980 by the International Union for the Conservation of Nature and Natural Resources (IUCN). The concept recognizes the interrelationship between social concerns, economic activity and the environment. However, in 1987, the Brundtland Commission in its report 'Our Common Future' defined the term sustainable development as "a development that meets the needs of the present without compromising the ability of futuregenerations to meet their own needs " [1]. Focusing on environment, a sustainable environment is considered as a way of life.Everyone becomes a steward of the land, and natural resources. Collectively we each take or use only what we need to live, and survive. Communities adopt a conserve and preserve mentality, creating an environment that is able meet the needs of present and future generations [2]. We did not want to put our environment at high risk as the environment is very complex and fragile. It made up of air, water, land, organic, non-organic and living organisms. When one small part of our eco-system is contaminated, such as water, the contamination sends out a ripple felt by all. Contaminated water, for example, affects plants, fish and eventually our food chain. No doubt that environmental risk is an important factor for any countries to evaluate their potential for economic and social sustainability. The definition of environmental risk is broad. For example,

Manuscript received May 31, 2013; revised August 7, 2013.

The authors are with the Department of Economics, Faculty of Economics and Management Sciences, International Islamic University Malaysia, Kuala Lumpur, Malaysia (e-mail: jarita@ iium.edu.my, rafia@ iium.edu.my). environmental risk is defined as a catastrophe, pesticide risk or the relative sustainability of the environment to social and economic activities (Yale Center for International Law and Policy and the Center for International Earth Science Information Network [3]. To have sustainable development definitely requires sustainable environment.

The objective of this paper is, therefore, to explore the contribution of economic development, population size or population density as well as the landlocked characteristic of the countries on the environmental performance using cross-sectional data of countries in the world listed by the United Nation (UN). The methods adopted in analyzing the relationship between environmental performance and the regressors are not limited to the Ordinary Least Square (OLS) method. More advance method of Generalized Method of Moments (GMM) is also adopted to provide robust results. The paper is organized as follows. Following this section, Section II looks at the research method followed by the discussion of findings in Section III. Finally, Section IV concludes.

\section{Data AND Method of ANALYsis}

\section{A. Environmental Performance Index (EPI)}

Over the years, interest has grown in developing indicators to measure 'sustainability'. Measures of sustainability tend to be a mixture of economic, environmental and social indicators. Environmental indicators tend to relate to sphere closest to human activity and can include economic, social and sustainability parameters too [4]. The goal of sustainable development is to achieve an equitable distribution of economic well-being that can be shared among present and future generations. This implies the utilization of renewable resources in ways which do not diminish their usefulness for the future and the depletion of non-renewable resources at a rate slow enough to ensure the high probability of a systematic transition to renewable sources. Thus, policies that support population growth which is unsuitable with economic conditions and consumerist living should be rejected. If one looks at one of $8^{\text {th }}$ the Millennium Development Goals (MDG), Goal 7 refers to "Ensure environmental sustainability" and list the following targets:

- Target 9: Integrate the principles of sustainable development into country policies and program and reverse the loss of environmental resources.

- Target 10: Halve, by 2015, the proportion of people without sustainable access to safedrinking water and basic sanitation.

- Target 11: Have achieved, by 2020, a significant improvement in the lives of at least 100 million slum dwellers. 
The Environmental Performance Index (EPI) is a method of quantifying and numerically benchmarking theenvironmental performance of a country's policies. This index was developed from the Pilot Environmental Performance Index, first published in 2002, and designed to supplement the environmental targets set forth in the U.N. Millennium Development Goals. The EPI uses outcome-oriented indicators, then working as a benchmark index that can be more easily used by policy makers, environmental scientists, advocates and the general public [3].

\section{B. Data and Methods}

In the present study, data are sourced from Yale Center for Environmental Law \& Policy and Center for International Earth Science Information Network at Columbia University. The environmental performance of the countries is measured using Environmental Performance Index (EPI) and its components: Environmental Health (ENVHEALTH) and Ecosystem Vitality (ECOSYSTEM). This is due the fact that the EPI 2010 centers on two broad environmental protection objectives: 1) reducing environmental stress on human health, and 2) promoting ecosystem vitality and sound natural resource management ${ }^{1}$.As for the economic development or growth, the Gross Domestic Product (GDP) per capita is used as an indicator. The indicators of population variable used are population size and population density measured by people per square $\mathrm{km}$. of land area. Besides, landlocked country dummy is also included to measure whether the country is entirely enclosed by land or only coastlines lie on closed seas. Historically, being landlocked (entirely enclosed by land) was regarded as a disadvantageous position. It cuts the country off from sea resources such as fishing, but more importantly cuts off access to seaborne trade which makes up large percentage of international trade. Coastal regions tended to be wealthier and more heavily populated than inland ones. For the landlocked dummy variable, we assign value of 1 for the country which is entirely enclosed by land and value 0 , otherwise.

In methodology, ordinary least squares (OLS) regressionsare estimated to determine factors that may have impact on a particular variable, with interaction effects are also used as independent variables. The dependent variable is the proxy of environmental performance, namely, Environmental Performance Index (EPI) of 2010 and its components such as Environment Health Index (ENVHEALTH) and Ecosystem Vitality Index (ECOSYSTEM) of similar year. The regressors (independent variables) consist of GDP per capita (2007) represents economic development or performance, population size of 2007 , population density of 2007 , landlocked dummy and previous year dependent variables, namely,EPI (2008), ENVHEALTH (2008) and ECOSYSTEM (2008).

Most importantly, another model developed in the present study is a multiple regression model in which the estimators are determined by GMM (Generalised Method of Moments)

${ }^{1}$ These objectives are gauged using 25 indicators tracked in 10 policy categories: Environmental Health, Air Pollution (effects on humans), Water (affects on humans), Air Pollution (affect on ecosystem), Water (affects on ecosystems), Biodiversity and Habitat, Forestry, Fisheries, Agriculture and Climate Change. methods of estimation instead of the OLS method. This model is dynamic (as compared to OLS model) in the sense that the set of explanatory variables includes some explanatory variables that are potentially jointly endogenous (in the sense of being correlated with the error term). Thus, the GMM method of estimation is used to capture this endogeneity problem. To obtain GMM estimates, we need to write the moment condition as an orthogonality condition between an expression including the parameters and a set of instrumental variables. For the GMM estimator to be identified, there must be at least as many instrumental variables as there are parameters to estimate. The estimation using EVIEWS is already corrected for heteroskedasticity of the unknown form using White Covariance test. The J-statistic will be reported and used to carry out hypothesis test from GMM estimation. In specific, the J-statistic is used to test the validity of overidentifying restrictions. Under the null hypothesis that the overidentifying restrictions are satisfied (means the model is 'valid'), the J-statistic times the number of regression observation is asymptotically $\chi^{2}$ with degree of freedom equal to the number of overidentifying restrictions.

\section{RESUlTS AND DISCUSSION}

The OLS regression results are displayed on Table I. Obviously, the previous environmental performances indices of 2008 are remain highly significant variables contribute to the present environmental indices of 2010. In equation 1 , except for previous index of 2008 (EPI 2008), other independent variables particularly the interaction variables are not significantly contribute to the EPI of the countries. From equation 2, beside previous ENVHEALTH index of 2008, two variables are seemed significantly affect ENVHEALTH 2010. Those are dummy landlock and the interaction of dummy landlock and GDP percapita. Coefficients of both variables are significant at 5 percent level and both are having opposite signs, positive and negative, respectively. This implies that when the country is enclosed entirely by land, the ENVHEALTH index is better without considering the country's economic development. But when there is economic development in the landlocked country, the ENVHEALTH index is worsened. In other words, the results suggest that economic development or economic performance will worsen the environmental health of the nations particularly for the countries who are entirely enclosed by land.Furthermore, in equation 3, using ECOSYSTEM 2010 as a dependent variable, similar variables of dummy landlock and the interaction of dummy landlock and GDP percapita are remain significant. However, both are having negative and positive signs, respectively. The results indicate that when the country is enclosed entirely by land, the ecosystem vitality is degrading without taken into account the economic development. But as there is economic development in the country or the country's economic performance increases, the ecosystem vitality is improving. The results, in general, suggest the importance of economic development or economic performance of the countries in improving their ecosystem, particularly for the countries which are entirely enclosed by land. 
TABLE I: DETERMINANTS OF EPI 2010, ENVHEALTH 2010 AND ECOSYSTEM 2010

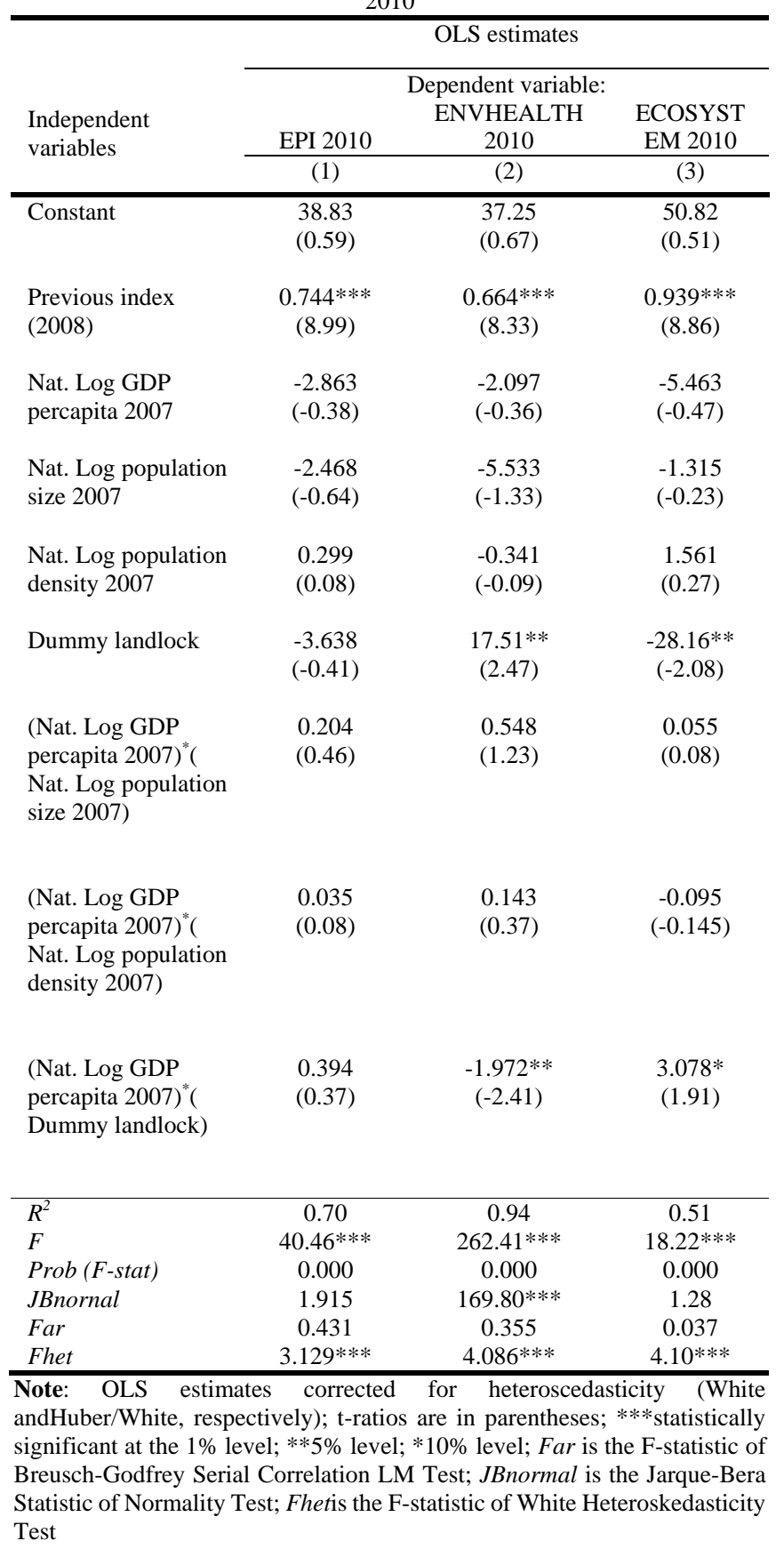

Table II shows the results obtained from the regression using the GMM method.Using overall index of environmental performance, EPI 2010 (equation 1), economic development measured by GDP per capita 2007 significantly contributes to the change in EPI 2010 of the countries. The positive sign of the coefficient indicates that economic development and performance of the countries are important to have improvement in their environmental performance. Moreover, in similar model, population size of 2007 also contributes significantly to EPI 2010 but with negative sign. This implies the adverse impact of population size on the overall environmental performance of the countries. Using ENVHEALTH 2010 as the indicator of environmental performance and a dependent variable, all independent variables significantly contribute to the environmental health. GDP per capita, which represents the economic development/ performance, contributes positively to environmental health, population size adversely affects the environmental health of the countries and the landlocked characteristic of the countries contributes positively to the environmental health. When ECOSYSTEM 2010 is used as the dependent variable, the results of equation 3 show that only GDP per capita significantly affects the ecosystem vitality of the countries. However, the impact is negative, which implies that more developed countries are having degradation of ecosystem vitality as compared to less developed countries.

TABLE II: EMPIRICAL RESULTS OF GMM METHOD

\begin{tabular}{lccc}
\hline & \multicolumn{3}{c}{ Dependent Variable: } \\
\cline { 2 - 4 } $\begin{array}{l}\text { Independent } \\
\text { Variable }\end{array}$ & EPI 2010 & $(2)$ & $(3)$ \\
& & 2010 & 2010 \\
\hline \multirow{2}{*}{ constant } & 10.42 & $-85.14 * * *$ & $107.89 * * *$ \\
& $(1.21)$ & $(-5.73)$ & $(4.55)$ \\
Nat. Log GDP & $7.95 * * *$ & $18.88^{* * * *}$ & $-7.48 * * *$ \\
percapita 2007 & $(14.45)$ & $(24.57)$ & $(-5.78)$ \\
& & & \\
Nat. Log & $-1.19 * * *$ & $-1.02 *$ & 0.835 \\
population size & $(-2.69)$ & $(-1.67)$ & $(0.89)$ \\
2007 & & & \\
Dummy & & $15.58 * *$ & -5.81 \\
landlock & 1.36 & $(-2.07)$ & $(-0.60)$
\end{tabular}

\begin{tabular}{|c|c|c|c|}
\hline $\begin{array}{l}\text { Included } \\
\text { observations }\end{array}$ & 143 & 143 & 143 \\
\hline $\begin{array}{l}\text { S.E of } \\
\text { regression }\end{array}$ & 9.89 & 13.66 & 15.81 \\
\hline$J$-statistic & 0.27 & 0.33 & 0.32 \\
\hline $\begin{array}{l}\text { Scalar overid } \\
\text { [p-value] }\end{array}$ & $\begin{array}{l}23.61 \\
{[0.09]}\end{array}$ & $\begin{array}{l}47.63 \\
{[0.00]}\end{array}$ & $\begin{array}{l}47.63 \\
{[0.00]} \\
\end{array}$ \\
\hline \multicolumn{4}{|l|}{$\begin{array}{l}\text { Diagnostic } \\
\text { tests: }\end{array}$} \\
\hline JBnormal & $18.45 * * *$ & $30.35 * * *$ & $5.37 *$ \\
\hline \multicolumn{4}{|l|}{$\begin{array}{l}\text { Ljung-Box } \\
\text { Q-stat: }\end{array}$} \\
\hline Lag $=1$ & 0.21 & 0.189 & 1.38 \\
\hline$L a g=2$ & 0.62 & 2.14 & 2.84 \\
\hline$L a g=3$ & 1.24 & 2.20 & 2.94 \\
\hline $\begin{array}{l}\text { Instrumental } \\
\text { list }\end{array}$ & \multicolumn{3}{|c|}{ 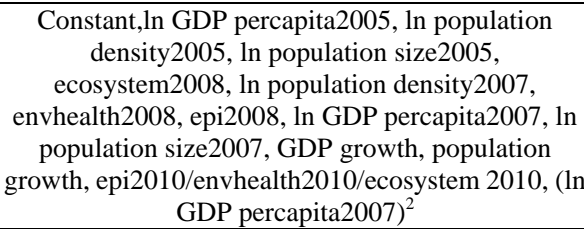 } \\
\hline
\end{tabular}

Notes1: t-statistic in parentheses; 2.JBnormal is the Jarque-Bera Statistic of Normality Test;Ljung-Box $Q$-statistics at lag $k$ is a test statistic for the null hypothesis that there is no autocorrelation up to order $\mathrm{k} ; 3$. *** significant at $1 \%$ level; ** significant at $5 \%$ level; *significant at $10 \%$ level.

\section{CONCLUSION AND POLICY IMPLICATION}

Overall, using EPI 2010 as a measurement of the effectiveness of national environmental protection effort, the present study finds that economic development/performance positively contributes to the countries' environmental performance which is not consistent with some previous studies [5]-[9]. On the other hand, population size gives negative impact on the environmental performance of the countries. It is also found that economic development contributes positively and significantly to the environmental health of the nations. On the other hand, ecosystem vitality of the countries is found to be adversely affected by their economic development and landlocked nature significantly. 
But if the landlocked countries are developed nations, this will improve their ecosystem as compared to those non-landlocked developed nations.

The findings simply indicate that economic development and high income level are important to ensure good environmental performance in most of the countries. High developed nations are normally more concern on environment through implementation of government policies.Governmental abatement effort to against pollution is good to the environment. So, environmental friendly governments are needed and more stringent environmental regulations should be adopted by the governments at all levels. And different abatement effort should be made by the central government to different pollutants and regions. Economic development strategies create the overarching "socioeconomic, cultural, and environmental conditions" that influence population health [10]. Creating a business climate and supporting public investments that contribute to goodpaying jobs can create an economically thriving community that strengthens education, social networks, and community resources, which in turn contributes to good health outcomes. Economic development plans also present an opportunity to make direct investments that can help prevent unnecessary illness and premature death from chronic diseases like heart disease, cancer, pulmonary disease, diabetes, and obesity - all of which have the same risk factors of diet, exercise, tobacco, and alcohol use. Investments that support disease prevention can also yield economic returns.Besides, the landlocked nature of the countries also contributes positively and significantly to the environmental health. However, given that the country is landlocked; her economic development will worsen her environmental health as compared to the non-landlocked countries. This signifies the importance of open location of the countries to improve their environmental health performance.

\section{REFERENCES}

[1] World Commission on Environment and Development (WCED), Our Common Future, London: Oxford University Press., 1987

[2] E. Blankenship. (2009). What is a sustainable environment? [Online]. Available:

http://www.helium.com/items/1336788-what-is-a-sustainable-environ ment

[3] Yale Center for Environmental Law \& Policy, and Center for International Earth Science Information Network at Columbia University (n.d.). Environmental Performance Index. [Online] Available:

http://research.yale.edu/envirocenter/index.php?page=environmentalperformance-index

[4] A. Fricker, "Measuring up to sustainability," Futures, vol. 30, no. 4, pp. 367-375. 1998

[5] N. Shafik, "Economic development and environmental Quality: An Econometric Analysis," Oxford Economic Papers, vol. 46, pp. 757-777, 1994.
[6] D. Holtz-Eakin and T. M. Selden. "Stoking the fires? $\mathrm{CO}_{2}$ emissions and economic growth," Journal of Public Economics, vol. 57, pp. $85-101,1995$

[7] A. W. Harbaugh, E. R. Banta, M. C. Hill, and M. G. McDonald,"MODFLOW-2000, the U.S. geological survey modular ground-water model-User guide to modularization concepts and the ground-waterflow process," USGS Open-File Report 00-92, Reston, Virginia: U.S. Geological Survey, 2000.

[8] M. Heil and T. M. Selden. "International trade intensity and carbon emissions: A cross-country econometric analysis," Journal of Environment \& Development, vol. 10, pp. 35-49, 2001

[9] F. Taskin and O. Zaim. "Searching for a Kuznets curve in environmental efficiency using kernel estimations," Economics Letters, vol. 68, pp. 217-223, 2000.

[10] G. Dahlgren and M. Whitehead, European strategies for tackling social inequities in health: Levelling up part 2, Copenhagen: WHO Regional Office for Europe, 2006.

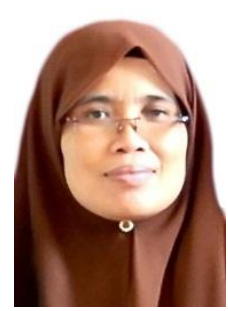

Jarita Duasa obtained her B. Soc. Scin. Economics in 1990 from University of Waikato, New Zealand and M.Econ (master in Economics) in 2000 from International Islamic University Malaysia. Her Ph.D. in Economics was conferred by the University of Sheffield, United Kingdom in 2005. She is serving the Department of Economics at Faculty of Economics and Management Sciences, International Islamic University Malaysia in teaching and research activities from year 2000. Her research niche areas are International Economics, International Finance and Applied Economics. She was promoted to associate professor in 2008 and to professor in 2012. She served as the post-graduate coodinator for Department of Economic from 2005 until 2010.

Prof. Jarita is actively involves in research and she won several awards in research such as, 2006 Quality Award in research at faculty level, the Outstanding Researcher for category of Social Sciences and Humanities in 2011 at university level and several others. Her work is made possible by her receipt of support in the form of grants from various agencies and ministries, at national and international levels. These include IIUM Research Grants as well as grants from the Malaysian Institute of Integrity (IIM), International Centre for Education in Islamic Finance (INCIEF) and PermodalanNasionalBerhad (PNB). Internationally, she also received grant from East Asia Development Network (EADN) on the project of ASEAN countries. She has published more than 30 articles in cited refereed journals, several books and edited books and presented over many papers at national and international conferences. She also actively supervises post-graduate theses at Master and Ph.D. levels. Besides, she is also one of the members of the Malaysian Finance Association (MFA).

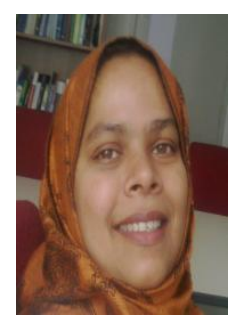

Rafia Afroz received her B.S.C. in Agricultural Economics in 1996 and M.S.C. in Production Economics in 1998 from Bangladesh Agricultural University and her Ph.D. in Environmental Planning and Management in 2004 from University Putra Malaysia.

Dr. Afroz is an assistant professor in International Islamic University Malaysia since 2008. Before that, Afroz was appointed as a senior lecturer in University Malaysia Sarawak in 2007. Afroz received JSPS Post Doc. Fellowship in the University of Tokyo in 2005. She published more than 30 articles in Journals and proceedings. Recently, she published one book entitled "The Peat Swamp: Productivity, Traficability and Mechanization" by Nova Science Publisher. Afroz's area of research interest is Environmental valuation, waste management, input output analysis and climate change. 